\title{
Association of the g.27563G $>$ A osteoprotegerin genetic polymorphism with bone mineral density in Chinese women
}

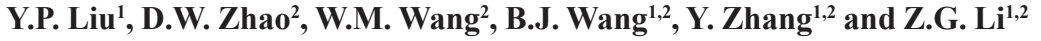 \\ ${ }^{1}$ Dalian University of Technology, Dalian, Liaoning Province, \\ China \\ ${ }^{2}$ Department of Orthopaedic Surgery, \\ The Affiliated Zhongshan Hospital of Dalian University, Dalian, \\ Liaoning Province, China \\ Corresponding authors: Y.P. Liu / D.W. Zhao \\ E-mail: yupeng_liu@sina.cn / dewei_zhao@sina.cn
}

Genet. Mol. Res. 13 (2): 3560-3566 (2014)

Received May 28, 2013

Accepted December 4, 2013

Published February 14, 2014

DOI http://dx.doi.org/10.4238/2014.February.14.9

\begin{abstract}
Osteoporosis is a common multifactorial disease in postmenopausal women. This study aimed to investigate the association of the g. $27563 \mathrm{G}>\mathrm{A}$ osteoprotegerin $(O P G)$ genetic polymorphism with bone mineral density (BMD) and osteoporosis. A case-control study was carried out with 435 osteoporosis postmenopausal women cases and 442 age-matched healthy controls. The BMD at the femoral neck hip, lumbar spine $\left(\mathrm{L}_{2-4}\right)$, and total hip were assessed by Norland XR-46 dual-energy X-ray absorptiometry. The genotypes of the g. $27563 \mathrm{G}>\mathrm{A}$ genetic polymorphism were detected by created restriction site-polymerase chain reaction and verified by DNA sequencing methods. We detected that the g. $27563 \mathrm{G}>\mathrm{A}$ genetic polymorphism was a non-synonymous mutation that resulted in an arginine (Arg) to glutamine (Gln) amino acid replacement
\end{abstract}


(p.Arg333Gln). Significant differences were found in the BMD of the femoral neck hip, lumbar spine $\left(\mathrm{L}_{2-4}\right)$, and total hip among different genotypes of the g.27563G $>$ A genetic polymorphism. Subjects with the genotype GG had significantly higher BMD values than those with genotypes GA and AA $(\mathrm{P}<0.05)$. Our data indicated that the A allele of the g. $27563 \mathrm{G}>\mathrm{A}$ genetic polymorphism in $O P G$ could be associated with lower BMD values in the Chinese postmenopausal women evaluated, and that it might be an increased risk factor for osteoporosis.

Key words: Bone mineral density; Osteoporosis; Osteoprotegerin gene; Genetic polymorphism; Risk factor; Chinese women

\section{INTRODUCTION}

Osteoporosis is a common and complex disease that is characterized by a reduction in bone mineral density (BMD) and a microarchitecture deterioration of bone tissue with a consequent increase of fracture risk (Cummings et al., 1985; Riggs and Melton III, 1986; Kanis et al., 1994; Geng et al., 2007; Garcia-Unzueta et al., 2008; Li et al., 2012; Woo et al., 2012). Osteoporosis is a major health problem in postmenopausal women. Recent large epidemiological studies have reported that low BMD is a major risk factor for osteoporosis (Nguyen et al., 2000; Lee et al., 2010; Ozbas et al., 2012) and that BMD is a complex trait that is determined by metabolic, genetic, and environmental factors. Several studies have shown that genetic factors play key roles in the development of osteoporosis (Nguyen et al., 2000; Ohmori et al., 2002; Albagha and Ralston, 2006; Ferrari, 2008; Cheung et al., 2010; Hosoi, 2010; Lee et al., 2010; Ralston, 2010; Feng et al., 2012; Ozbas et al., 2012; Woo et al., 2012; Zhang et al., 2013). Various candidate genes have been reported to influence BMD and osteoporosis, such as the osteoprotegerin $(O P G)$ gene (Pocock et al., 1987; Hofbauer and Schoppet, 2002; Langdahl et al., 2002; Yamada et al., 2003; Arko et al., 2002, 2005; Vidal et al., 2011; Feng et al., 2012; Hussien et al., 2013; Zhang et al., 2013), the transforming growth factor $\beta 1$ (TGF $\beta 1$ ) gene (Yamada, 2001), the collagen type 1a1 (COL1A1) gene (Mann and Ralston, 2003; Falcon-Ramirez et al., 2011), the estrogen receptor alpha (ER- $\alpha$ ) gene (Kurt et al., 2012), and the vitamin D receptor (VDR) gene (Fang et al., 2005; JakubowskaPietkiewicz et al., 2012; Kurt et al., 2012; Li et al., 2012; Hussien et al., 2013; Horst-Sikorska et al., 2013). The $O P G$ gene was first cloned and characterized by Morinaga et al. (1998), and has since been considered an important candidate gene for mediating the genetic influence on osteoporosis. In humans, some genetic polymorphisms of $O P G$, for example, A163G, T950C, T245G, G1181C, C21775T, G23276A, and T23367C, have been reported to influence BMD and osteoporotic fractures (Arko et al., 2002; Langdahl et al., 2002; Ohmori et al., 2002; Jorgensen et al., 2004; Zhao et al., 2005; Kim et al., 2007; Ueland et al., 2007; GarciaUnzueta et al., 2008; Moffett et al., 2008; Lee et al., 2010; Feng et al., 2012; Zhang et al., 2013). However, the potential association of the g. $27563 \mathrm{G}>$ A genetic polymorphism of $O P G$ with BMD and osteoporosis has not yet been investigated. In the present study, we aimed to examine the g.27563G $>$ A genetic polymorphism and investigated its effect on BMD and osteoporosis based on a case-control study. 


\section{MATERIAL AND METHODS}

\section{Subjects}

A case-control study was carried out with 435 osteoporosis postmenopausal women cases and 442 age-matched healthy controls. All subjects were of Chinese Han nationality and lived in Dalian city. Those suffering diseases or taking drugs that are known to affect skeletal homeostasis or interfere with bone metabolism were excluded. This study was approved by the local Ethics Committee. Informed consent forms were obtained from all subjects included in the study.

\section{Measurement of BMD}

BMD was quantified using Norland XR-46 dual-energy X-ray absorptiometry (Norland Coopersurgical Corp., USA) (Tothill et al., 1999) at lumbar spine $\left(\mathrm{L}_{2-4}\right)$, femoral neck hip, and total hip. The BMD value was calculated from bone mineral content $(\mathrm{g})$ and bone area $\left(\mathrm{cm}^{2}\right)$, and then expressed as $\mathrm{g} / \mathrm{cm}^{2}$. All BMD values were adjusted by age, weight, and height.

\section{Polymerase chain reaction (PCR) and genotyping}

Genomic DNA was isolated from peripheral venous blood using the Qiagen method (Hilden, Germany), and stored at $-80^{\circ} \mathrm{C}$ until analyzed. The PCR primers were constructed using the Primer Premier 5.0 software (Premier Biosoft International, Palo Alto, CA, USA). The PCR primers sequences, amplified fragment region, annealing temperature, and genotype size are shown in Table 1. The PCRs were performed in a total volume of $20 \mu \mathrm{L}$ containing $50 \mathrm{ng}$ mixed DNA template, $10 \mathrm{pM}$-each primer, $0.20 \mathrm{mM} \mathrm{dNTP,}, 2.5 \mathrm{mM} \mathrm{MgCl}_{2}$, and $0.5 \mathrm{U}$ Taq DNA polymerase (TianGen Biotech Inc., China). The PCR cycling conditions consisted of an initial denaturation step for $5 \mathrm{~min}$ at $94^{\circ} \mathrm{C}$, followed by 32 cycles for $30 \mathrm{~s}$ at $94^{\circ} \mathrm{C}, 30 \mathrm{~s}$ at $58.5^{\circ} \mathrm{C}$, and $30 \mathrm{~s}$ at $72^{\circ} \mathrm{C}$, and a final extension for $5 \mathrm{~min}$ at $72^{\circ} \mathrm{C}$. We detected the g. $27563 \mathrm{G}>\mathrm{A}$ genetic polymorphism through the created restriction site (CRS)-PCR method. Following the supplier manual, 5- $\mu \mathrm{L}$ aliquot PCR-amplified products were digested with $2 \mathrm{U}$ TaqI restriction enzymes (MBI Fermentas, St. Leon-Rot, Germany) at $37^{\circ} \mathrm{C}$ for $10 \mathrm{~h}$, which were separated by electrophoresis, and observed under UV light. DNA sequencing (ABI3730xl DNA Analyzer, Applied Biosystems, Foster City, CA, USA) was utilized to verify the accuracy of the genotype results obtained from the CRS-PCR method.

\section{Statistical analyses}

The chi-squared $\left(\chi^{2}\right)$ test was utilized to identify significant departures from HardyWeinberg equilibrium (HWE) for allele and genotype distributions. All data are reported as means \pm standard deviation (SD). The quantitative data were analyzed by one-way analysis of variance (ANOVA) and unpaired Student $t$-tests. The association analyses between different variables were evaluated by multiple regression analyses. A P value less than 0.05 was considered to be statistically significant. All statistical analyses were performed with the Statistical Package for Social Sciences software (SPSS 15.0; SPSS Inc., Chicago, IL, USA). 


\section{RESULTS}

\section{Genotyping of the $O P G$ genetic polymorphism}

A novel genetic polymorphism (g.27563G $>\mathrm{A}$ ) in $O P G$ was detected by the CRS-PCR method in the present study. The amplified PCR products were digested with TaqI restriction enzyme and divided into three genotypes: GG (190 and $21 \mathrm{bp}), \mathrm{GA}(211,190$, and $21 \mathrm{bp})$, and AA (211 bp) (Table 1). Results of sequence analyses suggested that this genetic polymorphism was a non-synonymous mutation in exon 5 at position 27,563 of the $O P G$ gene that was caused by a $\mathrm{G} \rightarrow \mathrm{A}$ mutation, and resulted in an arginine (Arg) to glutamine (Gln) amino acid replacement (p.Arg333Gln, reference sequences GenBank IDs: NG_012202.1, NM_002546.3, NP_002537.3).

Table 1. PCR and CRS-PCR analysis used for g.27563G $>$ A genetic polymorphism in the $O P G$ gene.

\begin{tabular}{lccccl}
\hline Primer sequences & $\begin{array}{c}\text { Annealing } \\
\text { temperature }\left({ }^{\circ} \mathrm{C}\right)\end{array}$ & $\begin{array}{c}\text { PCR amplification } \\
\text { fragment }(\mathrm{bp})\end{array}$ & Region & $\begin{array}{l}\text { Restriction } \\
\text { enzyme }\end{array}$ & Genotype (bp) \\
\hline 5'-CTGAAGCTGCTCAGTTTGTGTC-3' & 57.7 & 211 & Exon 5 & TaqI & $\begin{array}{l}\text { GG: 190, 21 } \\
\text { GA: 211, 190, 21 } \\
\text { 5'-CTGATTGGACCTGGTTACCTATC-3' }\end{array}$ \\
\hline
\end{tabular}

$\mathrm{PCR}=$ polymerase chain reaction; $\mathrm{CRS}-\mathrm{PCR}=$ created restriction site-PCR. Underlined nucleotide marks nucleotide mismatches enabling the use of the selected restriction enzymes for discriminating sequence variations.

\section{Allele and genotype frequencies}

The allele and genotype frequencies for the g.27563G $>$ A genetic polymorphism in osteoporosis cases and healthy controls are shown in Table 2 . The allele frequencies in osteoporosis cases $(\mathrm{G}, 64.60 \%$; $\mathrm{A}, 35.40 \%)$ were significantly different $\left(\chi^{2}=4.4666, \mathrm{P}=0.0346\right)$ from those of healthy controls $(\mathrm{G}, 69.34 \%$; A, 30.66\%). The genotype frequencies in osteoporosis cases (GG, 43.68\%; GA, 41.84\%; AA, 14.48\%) were significantly different $\left(\chi^{2}=6.3974, \mathrm{P}=0.0408\right)$ from those in healthy controls (GG, 47.74\%; GA, 43.21\%; AA, 9.05\%). Results from the $\chi^{2}$ test indicated that the genotype distributions were in line with HWE for the studied subjects $(\mathrm{P}>0.05)$.

Table 2. Allelic and genotypic frequencies of g. $27563 \mathrm{G}>$ A genetic polymorphism in the populations studied.

\begin{tabular}{|c|c|c|c|c|c|c|c|}
\hline \multirow[t]{2}{*}{ Groups } & \multicolumn{3}{|c|}{ Genotypic frequencies (\%) } & \multicolumn{2}{|c|}{ Allelic frequencies $(\%)$} & \multirow[t]{2}{*}{$\mathrm{P}$} & \multirow[t]{2}{*}{$\chi^{2}$} \\
\hline & GG & GA & AA & G & A & & \\
\hline Case group $(\mathrm{N}=435)$ & $190(43.68)$ & $182(41.84)$ & $63(14.48)$ & $562(64.60)$ & $308(35.40)$ & 0.2059 & 3.1612 \\
\hline Control group $(\mathrm{N}=442)$ & $211(47.74)$ & $191(43.21)$ & $40(9.05)$ & $613(69.34)$ & $271(30.66)$ & 0.9424 & 0.1186 \\
\hline \multirow[t]{2}{*}{ Total $(\mathrm{N}=877)$} & $401(45.73)$ & $373(42.53)$ & $103(11.74)$ & $1175(66.99)$ & $579(33.01)$ & 0.5249 & 1.2891 \\
\hline & \multicolumn{3}{|c|}{$\chi^{2}=6.3974, P=0.0408$} & \multicolumn{2}{|c|}{$\chi^{2}=4.4666, P=0.0346$} & & \\
\hline
\end{tabular}

\section{Association analysis between the $O P G$ genetic polymorphism and BMD}

The characteristics of cases and controls are shown in Table 3, including age, weight, height, body mass index, femoral neck hip BMD, spine BMD, and total hip BMD. Our data indicated that there were significant differences in femoral neck hip BMD, spine BMD, and 
total hip BMD among different genotypes in the studied subjects; subjects with the GG genotype showed higher BMD values compared to those with the GA and AA genotypes $(\mathrm{P}<0.05$; Table 3).

Table 3. Characteristics of $\mathrm{g} .27563 \mathrm{G}>$ A genetic polymorphism in the total population studied.
\begin{tabular}{lcccc}
\hline Genotype & GG & GA & AA & P \\
\hline Number $(\%)$ & $401(45.73)$ & $373(42.53)$ & $103(11.74)$ & - \\
Age (years) & $62.7 \pm 7.9$ & $63.3 \pm 7.1$ & $63.8 \pm 8.1$ & 0.445 \\
Height $(\mathrm{cm})$ & $161 \pm 8.2$ & $162 \pm 8.8$ & $165 \pm 6.9$ & 0.336 \\
Weight $(\mathrm{kg})$ & $61.1 \pm 6.6$ & $61.9 \pm 7.1$ & $62.6 \pm 7.2$ & 0.189 \\
BMI & $23.3 \pm 3.19$ & $23.6 \pm 3.18$ & $23.9 \pm 3.45$ & 0.227 \\
Femoral neck hip BMD $\left(\mathrm{g} / \mathrm{cm}^{2}\right)$ & $0.751 \pm 0.028$ & $0.687 \pm 0.112$ & $0.657 \pm 0.129$ & 0.038 \\
Spine BMD $\left(\mathrm{g} / \mathrm{cm}^{2}\right)$ & $0.951 \pm 0.106$ & $0.865 \pm 0.111$ & $0.841 \pm 0.185$ & 0.029 \\
Total hip BMD $\left(\mathrm{g} / \mathrm{cm}^{2}\right)$ & $0.892 \pm 0.116$ & $0.837 \pm 0.135$ & $0.812 \pm 0.284$ & 0.037 \\
\hline
\end{tabular}

$\mathrm{BMD}=$ bone mineral density (BMD values adjusted by age, height and weight); $\mathrm{BMI}=$ body mass index. Data are reported as means $\pm \mathrm{SD}$.

\section{DISCUSSION}

Osteoporosis, a major health problem in postmenopausal women, is a polygenic and multifactorial disease caused by the combined effects of genetic and environmental factors (Ohmori et al., 2002; Zhao et al., 2005). It is generally accepted that genetic factors play important roles in the pathogenesis of osteoporosis (Nguyen et al., 2000; Ohmori et al., 2002; Albagha and Ralston, 2006; Ferrari, 2008; Cheung et al., 2010; Hosoi, 2010; Lee et al., 2010; Ralston, 2010; Feng et al., 2012; Ozbas et al., 2012; Woo et al., 2012; Zhang et al., 2013). Because of the potentially important role of $O P G$ in controlling bone resorption, the $O P G$ gene is a candidate for mediating the genetic influence on BMD and osteoporosis (Pocock et al., 1987; Hofbauer and Schoppet, 2002; Langdahl et al., 2002; Yamada et al., 2003; Arko et al., 2002, 2005; Vidal et al., 2011; Feng et al., 2012; Hussien et al., 2013; Zhang et al., 2013). In this study, we assessed the relevance of genetic polymorphisms of $O P G$ in relation to BMD and osteoporosis through an association analysis. We firstly investigated the g.27563G $>$ A genetic polymorphism in exon 5 of $O P G$ using the CRS-PCR method. We then evaluated the potential association of this genetic polymorphism with BMD and osteoporosis. Results from this study demonstrated a statistically significant association between this genetic polymorphism and BMD and osteoporosis in Chinese postmenopausal women; subjects with the GG genotype had significantly higher BMD values compared to those with genotypes $\mathrm{GA}$ and $\mathrm{AA}(\mathrm{P}<0.05$; Table 3). Therefore, the A allele could be an increased risk factor for BMD and osteoporosis. Several similar studies have reported that genetic polymorphisms of $O P G$, such as A163G, T245G, T950C, G1181C, C21775T, G23276A, and T23367C, have potential associations with BMD and osteoporosis (Arko et al., 2002; Langdahl et al., 2002; Ohmori et al., 2002; Jorgensen et al., 2004; Zhao et al., 2005; Kim et al., 2007; Ueland et al., 2007; Garcia-Unzueta et al., 2008; Moffett et al., 2008; Lee et al., 2010; Feng et al., 2012; Zhang et al., 2013). Results from these observations are consistent with our findings that the genetic polymorphisms of $O P G$ may play key roles in contributing to the genetic influence on BMD and osteoporosis (Pocock et al., 1987; Hofbauer and Schoppet, 2002; Langdahl et al., 2002; Yamada et al., 2003; Arko et al., 2002, 2005; Vidal et al., 2011; Feng et al., 2012; Hussien et al., 2013; Zhang et al., 2013). According to the results of the sequence analyses, we found that the g. $27563 \mathrm{G}>\mathrm{A}$ 
genetic polymorphism is a non-synonymous mutation that resulted in an Arg to Gln amino acid replacement. This substitution might alter the function of the $O P G$ protein. In addition, this genetic polymorphism may be linked to other non-synonymous genetic polymorphisms, for example, Lysine (Lys) 3 Asparagine (Asn), Isoleucine (Ile) 184 Methionine (Met), and Threonine (Thr) 154Met, which have all been shown to be significantly associated with the risk of BMD and osteoporosis (Zhao et al., 2005; Feng et al., 2012; Zhang et al., 2013). Our study demonstrated that, for the g. $27563 \mathrm{G}>$ A genetic polymorphism, people carrying the GG genotype may have a lower risk of developing osteoporosis compared to those with the GA and AA genotypes (Table 3).

In conclusion, the present study, for the first time to the best of our knowledge, identified that the $O P G$ g. $27563 \mathrm{G}>\mathrm{A}$ genetic polymorphism could influence BMD and osteoporosis in Chinese postmenopausal women. Epidemiological investigations in other ethnicities or with a larger number of subjects are necessary to confirm our findings and to clarify the underlying molecular mechanism.

\section{Conflicts of interest}

The authors declare no conflict of interest.

\section{REFERENCES}

Albagha OM and Ralston SH (2006). Genetics and osteoporosis. Rheum. Dis. Clin. North Am. 32: 659-680.

Arko B, Prezelj J, Komel R, Kocijancic A, et al. (2002). Sequence variations in the osteoprotegerin gene promoter in patients with postmenopausal osteoporosis. J. Clin. Endocrinol. Metab. 87: 4080-4084.

Arko B, Prezelj J, Kocijancic A, Komel R, et al. (2005). Association of the osteoprotegerin gene polymorphisms with bone mineral density in postmenopausal women. Maturitas 51: 270-279.

Cheung CL, Xiao SM and Kung AW (2010). Genetic epidemiology of age-related osteoporosis and its clinical applications. Nat. Rev. Rheumatol. 6: 507-517.

Cummings SR, Kelsey JL, Nevitt MC and O’Dowd KJ (1985). Epidemiology of osteoporosis and osteoporotic fractures. Epidemiol. Rev. 7: 178-208.

Falcon-Ramirez E, Casas-Avila L, Miranda A, Diez P, et al. (2011). Sp1 polymorphism in collagen I alpha1 gene is associated with osteoporosis in lumbar spine of Mexican women. Mol. Biol. Rep. 38: 2987-2992.

Fang Y, van Meurs JB, d'Alesio A, Jhamai M, et al. (2005). Promoter and 3'-untranslated-region haplotypes in the vitamin D receptor gene predispose to osteoporotic fracture: The Rotterdam Study. Am. J. Hum. Genet. 77: 807-823.

Feng G, Meng L, Wang H, Lu Y, et al. (2012). Single-nucleotide polymorphism of the osteoprotegerin gene and its association with bone mineral density in Chinese postmenopausal women. J. Pediatr. Endocrinol. Metab. 25: 11411144.

Ferrari S (2008). Human genetics of osteoporosis. Best. Pract. Res. Clin. Endocrinol. Metab. 22: 723-735.

Garcia-Unzueta MT, Riancho JA, Zarrabeitia MT, Sanudo C, et al. (2008). Association of the 163A/G and 1181G/C osteoprotegerin polymorphism with bone mineral density. Horm. Metab. Res. 40: 219-224.

Geng L, Yao Z, Yang H, Luo J, et al. (2007). Association of CA repeat polymorphism in estrogen receptor beta gene with postmenopausal osteoporosis in Chinese. J. Genet. Genomics 34: 868-876.

Hofbauer LC and Schoppet M (2002). Osteoprotegerin gene polymorphism and the risk of osteoporosis and vascular disease. J. Clin. Endocrinol. Metab. 87: 4078-4079.

Horst-Sikorska W, Dytfeld J, Wawrzyniak A, Marcinkowska M, et al. (2013). Vitamin D receptor gene polymorphisms, bone mineral density and fractures in postmenopausal women with osteoporosis. Mol. Biol. Rep. 40: 383-390.

Hosoi T (2010). Genetic aspects of osteoporosis. J. Bone Miner. Metab. 28: 601-607.

Hussien YM, Shehata A, Karam RA, Alzahrani SS, et al. (2013). Polymorphism in vitamin D receptor and osteoprotegerin genes in Egyptian rheumatoid arthritis patients with and without osteoporosis. Mol. Biol. Rep. 40: 3675-3680.

Jakubowska-Pietkiewicz E, Mlynarski W, Klich I, Fendler W, et al. (2012). Vitamin D receptor gene variability as a factor influencing bone mineral density in pediatric patients. Mol. Biol. Rep. 39: 6243-6250. 
Jorgensen HL, Kusk P, Madsen B, Fenger M, et al. (2004). Serum osteoprotegerin (OPG) and the A163G polymorphism in the OPG promoter region are related to peripheral measures of bone mass and fracture odds ratios. J. Bone Miner. Metab. 22: 132-138.

Kanis JA, Melton LJ III, Christiansen C, Johnston CC, et al. (1994). The diagnosis of osteoporosis. J. Bone Miner. Res. 9: 1137-1141.

Kim JG, Kim JH, Kim JY, Ku SY, et al. (2007). Association between osteoprotegerin (OPG), receptor activator of nuclear factor-kappaB (RANK), and RANK ligand (RANKL) gene polymorphisms and circulating OPG, soluble RANKL levels, and bone mineral density in Korean postmenopausal women. Menopause 14: 913-918.

Kurt O, Yilmaz-Aydogan H, Uyar M, Isbir T, et al. (2012). Evaluation of ERalpha and VDR gene polymorphisms in relation to bone mineral density in Turkish postmenopausal women. Mol. Biol. Rep. 39: 6723-6730.

Langdahl BL, Carstens M, Stenkjaer L and Eriksen EF (2002). Polymorphisms in the osteoprotegerin gene are associated with osteoporotic fractures. J. Bone Miner. Res. 17: 1245-1255.

Lee YH, Woo JH, Choi SJ, Ji JD, et al. (2010). Associations between osteoprotegerin polymorphisms and bone mineral density: a meta-analysis. Mol. Biol. Rep. 37: 227-234.

Li Y, Xi B, Li K and Wang C (2012). Association between vitamin D receptor gene polymorphisms and bone mineral density in Chinese women. Mol. Biol. Rep. 39: 5709-5717.

Mann V and Ralston SH (2003). Meta-analysis of COL1A1 Sp1 polymorphism in relation to bone mineral density and osteoporotic fracture. Bone 32: 711-717.

Moffett SP, Oakley JI, Cauley JA, Lui LY, et al. (2008). Osteoprotegerin Lys3Asn polymorphism and the risk of fracture in older women. J. Clin. Endocrinol. Metab. 93: 2002-2008.

Morinaga T, Nakagawa N, Yasuda H, Tsuda E, et al. (1998). Cloning and characterization of the gene encoding human osteoprotegerin/osteoclastogenesis-inhibitory factor. Eur. J. Biochem. 254: 685-691.

Nguyen TV, Blangero J and Eisman JA (2000). Genetic epidemiological approaches to the search for osteoporosis genes. J. Bone Miner. Res. 15: 392-401.

Ohmori H, Makita Y, Funamizu M, Hirooka K, et al. (2002). Linkage and association analyses of the osteoprotegerin gene locus with human osteoporosis. J. Hum. Genet. 47: 400-406.

Ozbas H, Tutgun OS and Ozdamar K (2012). Genetic and environmental factors in human osteoporosis. Mol. Biol. Rep. 39: 11289-11296.

Pocock NA, Eisman JA, Hopper JL, Yeates MG, et al. (1987). Genetic determinants of bone mass in adults. A twin study. J. Clin. Invest. 80: 706-710.

Ralston SH (2010). Genetics of osteoporosis. Ann. N. Y. Acad. Sci. 1192: 181-189.

Riggs BL and Melton LJ III (1986). Involutional osteoporosis. N. Engl. J. Med. 314: 1676-1686.

Tothill P, Laskey MA, Orphanidou CI and van Wijk M (1999). Anomalies in dual energy X-ray absorptiometry measurements of total-body bone mineral during weight change using Lunar, Hologic and Norland instruments. $\mathrm{Br}$. J. Radiol. 72: 661-669.

Ueland T, Bollerslev J, Wilson SG, Dick IM, et al. (2007). No associations between OPG gene polymorphisms or serum levels and measures of osteoporosis in elderly Australian women. Bone 40: 175-181.

Vidal C, Formosa R and Xuereb-Anastasi A (2011). Functional polymorphisms within the TNFRSF11B (osteoprotegerin) gene increase the risk for low bone mineral density. J. Mol. Endocrinol. 47: 327-333.

Woo J, Kim Y and Lee C (2012). Heterogeneous genetic associations of nucleotide sequence variants with bone mineral density by gender. Mol. Biol. Rep. 39: 2259-2265.

Yamada Y (2001). Association of polymorphisms of the transforming growth factor-beta1 gene with genetic susceptibility to osteoporosis. Pharmacogenetics 11: 765-771.

Yamada Y, Ando F, Niino N and Shimokata H (2003). Association of polymorphisms of the osteoprotegerin gene with bone mineral density in Japanese women but not men. Mol. Genet. Metab. 80: 344-349.

Zhang F, He C, Chen G, Li F, et al. (2013). Association analyses of osteoprotegerin gene polymorphisms with bone mineral density in Chinese postmenopausal women. Med. Oncol. 30: 389.

Zhao HY, Liu JM, Ning G, Zhao YJ, et al. (2005). The influence of Lys3Asn polymorphism in the osteoprotegerin gene on bone mineral density in Chinese postmenopausal women. Osteoporos. Int. 16: 1519-1524. 